\section{Contributions to the Cytology of Indian Scorpions}

The cytology of scorpions is interesting and intriguing ${ }^{1-13}$. The diploid number of chromosomes of Heterometrus scaber is 96 (Figure a). The chromosome number of $H$. fulvipes collected in Madras and Tirupati (South India) is 88 (Figure b) as against 86 of North India ${ }^{\mathbf{1 4}}$. The chromosome number of Buthus tamulus varies from 20 to 28 ; the commonest number is 24 (Figure $\mathrm{c}$ ). The chromosome number of the same species found in North India is 23 and is stable. The variability is due to fragmentation-fusion heterozygosity, which has a bearing on the geographical locale, as found in Tityus bahiensis ${ }^{1}$ and Buthus tamulus of Mysore, which probably reflects their adaptability to various environments ${ }^{15}$. The anaphase $I$ chromosomes of $H$. scaber and $H$. fulvipes, by virtue of their long axis being parallel to the main axis of the spindle, have been designated as monocentric and acrocentric chromosomes (Figures $f$ and $g$ ). The chromosomes at no stage show any constriction suggestive of the location of the kinetochore. Chromosomes of Palamnaeus swammerdami also have a similar morphology ${ }^{9}$, but when $0.2 \%$ colchicine was injected into males, the chromosomes showed at pre-metaphase I distinct subterminal, sub-
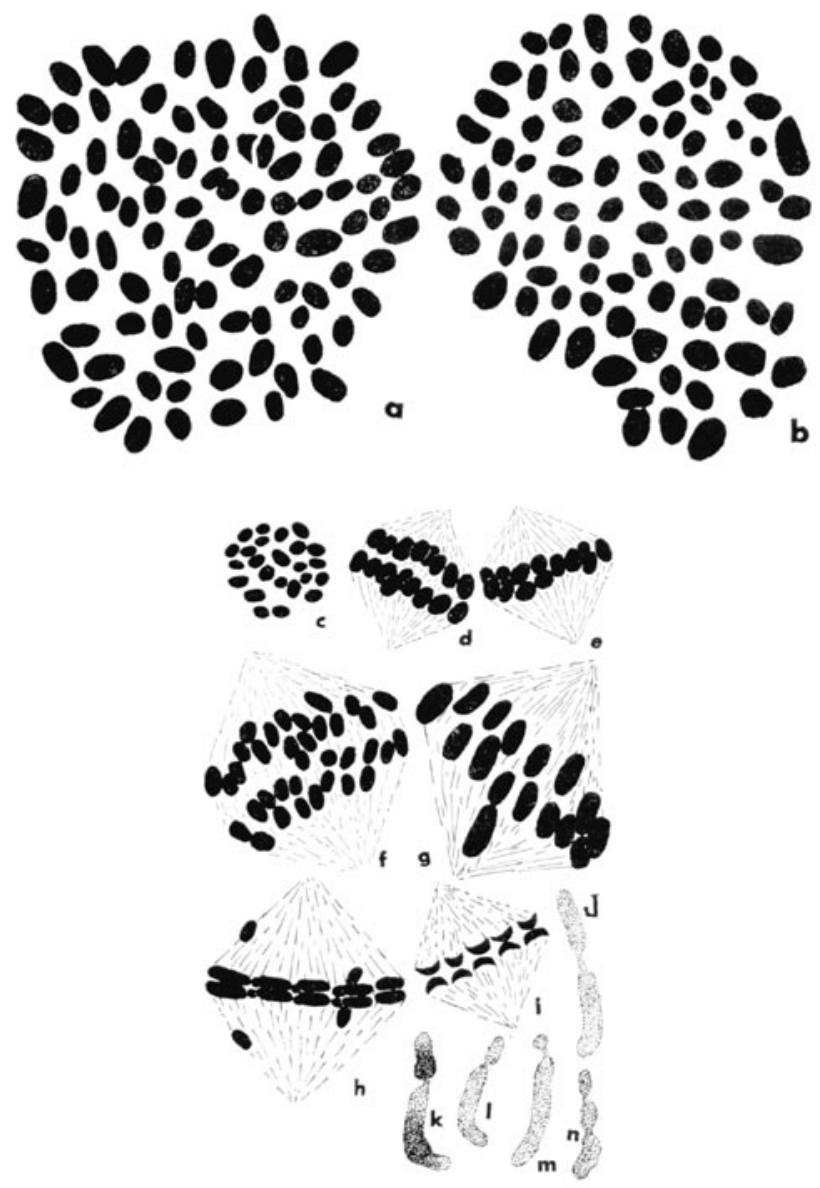

Fig. a, Gonial plate of $H$. scaber. b, Gonial plate of $H$. Iulvipes. $c$, Gonial plate of $B$, tamulus. $d$, Anaphase $I$ of $B$. tamulus. e, Metaphase I of $B$, tamulus. $\mathrm{f}$, Anaphase I of $H$. scaber. g, Anaphase I of

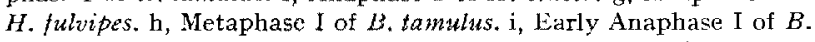
tamulus, $\mathrm{j}, \mathrm{k}, 1$, and $\mathrm{m}$. Pre-metaphase $\mathrm{I}$ chromosomes of $P$. swammerdami (colchicine treated) showing single constriction. $\mathrm{n}$, showing double constriction. (Camera lucida, $\times 4000$.) metacentric, and metacentric constrictions (Figures $\mathrm{j}$ to $\mathrm{m})$. Some show two constrictions (Figure n). This is due to hypocoiling of the chromosomes. While the possibility of colchicine inducing constrictions unrelated to kinetochore exists, the revealing of unseen constrictions is of interest.

The chromosome behaviour in Buthus tamulus of South India is unique because, in the testicular cells of the same individual, the following three types of orientation at metaphase $I$ and anaphase $I$ are cncountered: (1) the axes of chromosomes are at right angles to the equatorial plate, suggesting monocentry (Figure d); (2) the axes of chromosomes are parallel to the equatorial axis, suggesting diffused or holokinetic nature (Figure $h$ ); and (3) the crescentic appearance of chromosomes, suggesting bicentry (Figure i). The crescentic nature of chromosomes of B. tamulus of Mysore State are amenable for interpretation as monocentric, bicentric, and holokinetic. This observation warrants a reassessment of our opinion not only of kinetochore but also the axis relationships as criteria for designation of chromosome types. This is especially so in the light of the observations of RHOADES and VELKOMERSON ${ }^{16}$ on plant chromosomes, in which they have shown 'neocentric' activity of non-centromeric regions of the chromosome. Further, chromosomes of $B$. tamulus designated as monocentric cannot be reconciled with the fact that there is a higher degree of variability interpretable only by breakage and retention of chromosome bits in the karyotype. This observation can be explained only on the basis of the holokinetic nature of the chromosomes.

Zasammenfassumg. Die Chromosomenzahl von Heterometrus scaber ist 96 . Wird Palamnaeus swammerdami mit Colchicin $(0,2 \%)$ behandelt, so ziehen sich die Chromosomen in der Prämetaphase I zusammen. Buthus tamulus (aus Mysore) zeigt weitgehend variable Chromosomenzahl (20-28). Die Lage der Chromosomen in der Metaphase I und Anaphase 1 weist auf Monozentrie, Bizentrie und Holokinetie.

C. B. VENKATANARASIMHIAH and M. R. RajasekarasetTy

Department of Post-Graduate Studies in Zoology, Manasagangotri, University of Mysove (India), October 21, 1964 .

1 S. de Toledo PuzA, Gen. iber. 2, 2 (1950).

2 S. DE Toledo Prza, Canad. Entomol. 89, 12 (1957).

3 S. ne Toledo PlzA, Rev. Agric. 36, 4 Deyem (1961)

4 E. R. Walson, J. Morph. 52, 429 (1931).

s. G. P. Sharma, R. Parshad, and M. G. Jonfja, Res. Bull. (N.S.) Punjab Univ, 10,197 (1959).

* V. Nath, Ouart. I. micr. Soc. 69, 643 (1925).

7G. P. SHARMA, R. PARSLAw, and R. HANDA, Quart. J. micr. Soc $13,85(1962)$

8 C. B. VENKATANARASIMULAH and M. R. Ra JASE KaRASETTY, Caryologia $77,195(1964)$

9. B. Venkatanarastmhiah, Mys. Univ. J., in press (1964),

$10 \mathrm{H}$. A. Guenin, Vie et Milieu 71, 1 (1961).

11 M. M. Rhoades and W. E. Kerr, Proc. Nat. Acad. Sci. 35, 129 (1949).

12 S. DE TOIEDO PIZA, Gen, iber, 2, 193 (1950).

13 S. H. Schrader and R. SCHRAder, Chromosoma 12, 327 (1961).

14 G. P. Sharma, R. Parsilad, and R. Hainda, Res. Bull. (N.S.) Punjab Univ, 13, 85 (1962).

15 M. R. Rajasekarasext $Y$ and C. B. Venkatanarasimhiah, unpublished.

16 M. M. Rhondes and H. Ver komerson, Proc. nat. Acad. Sci. Wash. 35, 129 (1942). 